\title{
Impact of gender on small and medium-sized entities' access to venture capital in South Africa
}

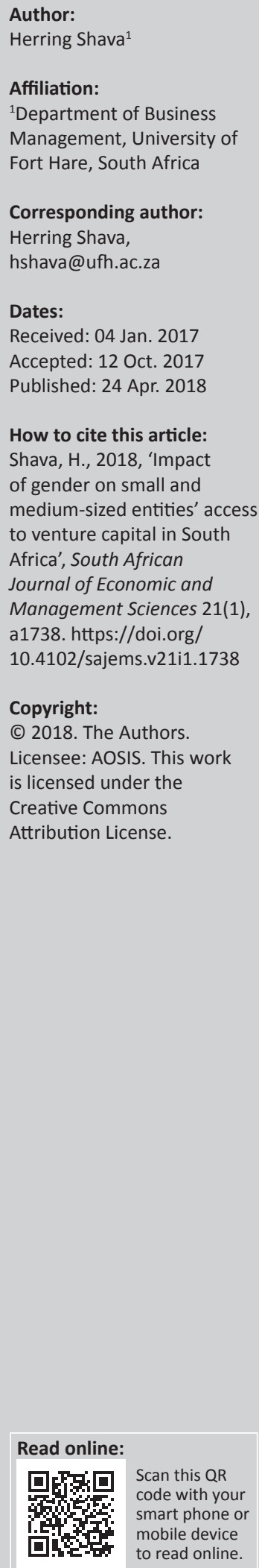

Background: The debate on the influence of gender on small and medium-sized entities' (SMEs) access to finance from a demand-side perspective is still ongoing. This study seeks to contribute to the debate from an emerging economy (South Africa) perspective.

Aim: The study investigated whether there is a gender gap in SME access to venture capital, a distinct source of finance.

Setting: SMEs play a significant role in South Africa's economy. Despite the importance of SMEs, access to finance is one of the major constraints affecting their success rate. Globally, to enhance the probability of SME survival, small business practitioners and governments are in search of relevant support measures. One of those measures could be adequate access to venture capital. However, it is sad to note that SMEs seldom use this distinct source of finance.

Methods: The study made use of the quantitative method of research and is descriptive by design. Self-administered questionnaires were emailed to respondents for the purposes of gathering primary data. The $t$-test was used to statistically analyse primary data.

Results: The results reveal that there is a statistically significant difference in the accessibility of venture capital between male- and female-owned SMEs.

Conclusion: The article concludes that a gender gap in access to venture capital exists owing to differences in business approach between female entrepreneurs and their male counterparts. Female entrepreneurs are cautious about the level of risk they are willing to take and the amount of control they wish to exercise in firm ownership.

\section{Introduction}

In contrast to previous years, policymakers in developing nations are currently stepping up efforts to promote economic expansion activities of female-owned enterprises (Klapper \& Parker 2011). The role played by female-owned business entities in reducing unemployment and the inequality gap in societies cannot be overlooked (Noguera, Alvarez, Merigó \& Urbano 2015). The establishment of financial institutions such as the Grameen Bank in Bangladesh, characterised by microfinance schemes that specialise in lending small loans to impoverished female enterprise owners regardless of collateral, testifies to the pivotal role female-owned enterprises play in societies (Kumar, Hossain \& Gope 2015). Despite the importance of female entrepreneurship across the globe, female-owned firms are more likely to terminate operating activities within 5 years of operation owing to limited access to financial resources, such as venture capital (Cant \& Wiid 2013; Fatoki \& Smit 2011; Flowers et al. 2013). According to Korteweg and Nagel (2016), investments by venture capitalists are a crucial source of funding that has proven to be valuable in supporting young firms and ensuring their success in the economy.

This article considers a distinct source of funds in the form of venture capital, which plays a crucial role in small and medium-sized entity (SME) start-ups and growth (Lucey 2010). Besides the provision of equity (venture capital) to fast-growing privately owned firms, venture capital fund managers have advanced expertise in contract negotiations, and hence they function as financial intermediaries, managers, and often as directors (Kortum \& Lerner 2000). Research reveals that in some countries, for example the United States of America (USA), venture capital is the major contributor to growth and success of SMEs in sectors such as biotechnology and information communication technology (Gompers \& Lerner 2001; Jeng \& Wells 2000). Memba, Gakurwe and Karanga (2012), in their study conducted in Kenya, concluded that venture capitalists' investment in SMEs facilitated wealth creation in ways that improved people's livelihoods. Memba et al. (2012) further argued that venture capital is the best source of business finance, although it is seldom used. In addition, their findings revealed that venture capital has a positive impact on SME growth. 
Conversely, Brush, Carter, Gatewood, Greene and Hart (2004) indicated that male-owned firms access formal and informal venture capital better than female-owned firms do. Thus, to a certain degree, research suggests that gender is an influencing factor regarding the above-mentioned differences. Empirical evidence focusing on the influence of gender on SME access to venture capital is limited. Scholars such as Derera, Chitakunye and O'Neill (2014) indicated that studies focusing on women entrepreneurial activities are needed, particularly in developing nations such as South Africa. This article is a response to this call by adopting a different dimension and investigating whether or not male- and female-owned SMEs have a significant differential access to venture capital. The empirical study contributes significantly to the literature and unveils imbalances in practice and adoption of the entrepreneurship concept within societies. The remaining part of the article is structured as follows: literature review, research methodology, results and discussion, recommendations, and finally the conclusion to the study.

\section{Literature review}

Venture capitalists rely more on the concept of asymmetric information as it gives preference to issues of 'selection and governance' which are key to their success. Osnabrugge (2000) pointed out that in a normal business environment, asymmetric information leads to agency problems, which prove to be an adverse selection and moral hazard. This study, however, gives preference to moral hazard as it is well associated with the concept of gender in the sense that both male and female SME owners are somehow affected by how they can best align their own interest in the firm, versus the interests of venture capitalists. In undertaking investment decisions, venture capitalists seriously take into account the firm owner's interest and future goals, such as growth. The owner's interest in firm growth is a key indicator in assessing the firm's risk. Thus, venture capitalists undertake and implement nearly all possible risk mitigation measures available to them in order to reduce the uncertainty of the investment outcome.

This literature review section provides a detailed discussion on the nature of venture capital and the current outlook of venture capital in South Africa. Literature focusing on gender differences and access to venture capital is reviewed. Thereafter, literature focusing on the relationship between gender, business risk, and access to finance is reviewed.

\section{The nature of venture capital}

Venture capital refers to investments made by venture capitalists at budding or start-up stages of business (Correia, Flynn, Uliana \& Wormald 2011). Venture capital is managed by venture capital fund managers who are individuals who provide value-added resources to entrepreneurs in the form of strategic advice, managerial expertise, technical expertise, and financial, administrative, and marketing support activities depending on the needs of the investee (Dorsey 1979; Fatoki 2012). Venture capital fund managers also go a step further to link entrepreneurial firms to business networks of accountants, lawyers, investment bankers, and other business organisations operating in the same sector as the investee (Cumming \& Johan 2013). Venture capital is different from private equity in the sense that the latter is broader in scope as it can be used for various purposes such as investment at a later stage of business (after start-up), or for buyout purposes and as investment to change the scope of business in the form of turnaround investments (Cumming \& Johan 2013). Table 1 indicates different financing stages where venture capital is applicable and where it has been utilised the most.

\section{Venture capital in South Africa}

Venture capitalists in South Africa are formal firms owned by individuals who excelled in different endeavours in the past. They constantly monitor enterprises in which they have invested and they are very conservative (Small Enterprise Development Agency [SEDA] 2016). They are conservative in the sense that they take a different approach from the European and USA venture capitalists when making investments. The trend overseas is that out of 10 recipients of venture capital funding, 6 stand to fail and 3 stand a chance to break even with only 1 entity likely to make a substantial amount of money for both the owner and venture capitalists (SEDA 2016). Venture capitalists in South Africa shy away from such huge risks and they are very sceptical about investing in SMEs, an approach that has seen them being successful and losing very little. Similar to other venture capital firms worldwide, South African venture capital firms have clearly defined exit strategies outlined in the contracts they negotiate with the SME owners (Gitman et al. 2010). The organisation of South African venture capital investors is outlined in Table 2.

Generally, venture capital investments are concluded through a legal contract that allocates responsibilities and ownership interests between existing owners and the venture capital fund or limited partnership, also taking into consideration the firm's development stage (Gitman et al. 2010).

According to the South African Venture Capital Association (SAVCA 2013), a private equity industry survey reported that

TABLE 1: Venture capital financing stages.

\begin{tabular}{ll}
\hline Stage & Finance purpose \\
\hline Seed & $\begin{array}{l}\text { At the seed stage, venture capitalists provide entrepreneurs } \\
\text { with funding to undertake research, to evaluate and develop } \\
\text { the business idea or concept before the business can be } \\
\text { officially commissioned (start-up phase). }\end{array}$ \\
$\begin{array}{l}\text { Once the business concept has been successfully developed } \\
\text { (prototype), venture capitalists provide finance to } \\
\text { entrepreneurs to enable product and service development and } \\
\text { to fund the marketing of the product or service. At this time, } \\
\text { the business may be at varying stages of the start-up process, } \\
\text { for example in the setup stage or the business may have been } \\
\text { operating for a foreseeable period. However, at this stage the } \\
\text { business will not have commercially sold the product or service. }\end{array}$ \\
$\begin{array}{l}\text { Venture capitalists also provide finance to entrepreneurs who } \\
\text { have successfully completed the product development stages } \\
\text { but lack funding to finance the actual production of the product } \\
\text { or rendering of the service at a commercial level for sales in } \\
\text { order to generate profits. }\end{array}$ \\
\hline
\end{tabular}

Note: Please see the full reference list of the article, Shava, H., 2018, 'Impact of gender on small and medium-sized entities' access to venture capital in South Africa', South African Journal of Economic and Management Sciences 21(1), a1738. https://doi.org/10.4102/ sajems.v21i1.1738, for more information. 
TABLE 2: Organisation of institutional venture capital investors in South Africa.

\begin{tabular}{ll}
\hline Organisation & Description \\
\hline $\begin{array}{l}\text { Financial venture } \\
\text { capital funds }\end{array}$ & $\begin{array}{l}\text { They constitute subsidiaries of financial institutions, } \\
\text { particularly banks, set up to help young firms to grow } \\
\text { with the hope that they will become major } \\
\text { institutions. }\end{array}$ \\
$\begin{array}{l}\text { Corporate venture } \\
\text { capital funds }\end{array}$ & $\begin{array}{l}\text { These are firms and sometimes subsidiaries that are } \\
\text { established by non-financial firms typically to gain } \\
\text { access to new technologies. Establishing firms } \\
\text { negotiate access to such new technologies so as to } \\
\text { further their own growth in the future. }\end{array}$ \\
$\begin{array}{l}\text { Venture capital limited } \\
\text { partnerships }\end{array}$ & $\begin{array}{l}\text { They are limited partnerships organised by } \\
\text { professional venture capital firms, which serve as } \\
\text { general partner and therefore organise, invest, and } \\
\text { manage the partnership using the limited partners' } \\
\text { funds. The professional venture capitalist ultimately } \\
\text { liquidates the partnership and distributes the proceeds } \\
\text { to all partners. }\end{array}$ \\
\hline
\end{tabular}

Source: Gitman, L.J., Smith, M.B., Hall, J., Lowies, B., Marx, B., Strydom, B. et al., 2010, Principles of managerial finance: Global and Southern African perspectives, Pearson Education South Africa (Pty) Ltd., Cape Town

the South African local private equity industry added $10.4 \%$ to its total funds under management accumulating to R126.4 billion as of December 2012. This increase reportedly surpassed the previous 4 years' combined cumulative growth of $4.6 \%$. Factors behind the observed $10.4 \%$ growth include the renewed interest of global investors to invest in the South African market. According to SAVCA (2013), investors in developed markets, such as in the USA and Europe, are in search of growth assets that are not apparent in their domestic markets. Resultantly, the South African private equity managers present an attractive, sophisticated and low risk opportunity to such investors (SAVCA 2013). Furthermore, another factor that led to the increased activity in the private equity sector in 2012 was the announcement by the South African Government Employees Pension Fund (GEPF) that it intended to deploy up to R60 billion into private equity over the forthcoming years (SAVCA 2013).

Funds that SAVCA raised in the year 2012 amounted to R14.4 billion, rising from R10.7 billion in 2011, a figure lower than the record level of R15.4 billion realised in the year 2007. In the year 2012, investments of R10.6 billion were made; however, this was a low figure compared to investments realised in the year 2011. Significant investment activities were to be undertaken in the final quarter of the year 2013 which were expected to continue into the year 2014, given that at that time the association had availed approximately R35.3 billion in undrawn commitments (SAVCA 2013).

The value or estimate of the management advice (value addition) provided by venture capital fund managers to the various firms in South Africa is not clear. However, it is probable that the skill improvement effect of venture capital is a significant additional benefit. Although venture capital makes a limited contribution to the equity gap in South Africa, it should be noted that the funds, and managerial and technical support, they provide remain limited compared to the needs of the SME sector (SAVCA 2013).

As of today, the South African private equity sector is one of the most developed, with R29 billion under management at the end of the year 2015. This figure is a significant increase of
145\% when compared to R11 billion raised in the year 2014 (SAVCA 2015). Approximately R22 billion of the R29 billion came from South African investors dominated by fund managers who oversee investments of third parties. Investments concluded in the year 2015 were as follows: R4.4 billion on follow-up investments, and R6.1 billion on new investments. A total of 534 deals were concluded in the year 2015, with the most notable as follows: $15.9 \%$ of the deals were concluded with entrepreneurs through banks, financial services, and insurance; $15.7 \%$ of the deals were concluded with entrepreneurs in the retail sector, $14.2 \%$ were deals concluded with entrepreneurs in the infrastructure sector, and $11.8 \%$ of the deals were concluded with entrepreneurs operating in the manufacturing sector (SAVCA 2016).

\section{Gender differences and access to venture capital}

Carter, Shaw, Wilson \& Lam (2006) observed that women business entity owners may be disadvantaged in their access to various entrepreneurial resources, given their personal backgrounds and employment experience, as well as the socioeconomic and cultural context in which their businesses operate. Evidence from various studies indicate that women's access to formal finance is lower than that of men (Ellis, Cutura, Dione, Gillison, Manuel \& Thongori 2007; Global Entrepreneurship Monitor [GEM] \& International Finance Corporation [IFC] 2005; Faisel 2004; Richardson, Howarth \& Finnegan 2004). Naidoo, Hilton and Natalie (2006) revealed that female entrepreneurs in South Africa face various challenges in accessing formal finance. For example, after 2 years of operations, the Black Economic Empowerment (BEE) equity fund only had a total of $5 \%$ female clients. Research by Klapper and Parker (2011) pointed out that established financial houses grant finance to male applicants at a more affordable rate than they do to female applicants. However, Muravyev, Schafer and Talavera (2009) took a different dimension to this debate and argued that even if women succeed in acquiring finance, it will be associated with high finance costs compared to men.

However, Greene, Brush, Hart \& Saparito (2001) revealed alarming statistics when focusing on equity investments in the USA during 1998. With regard to venture capital, a low figure of $4.1 \%$ was channelled to female-owned firms. Surprisingly, $40 \%$ of firms were female-owned in the same year, yet they received less than $5 \%$ of venture capitalists' funds. This suggests that gender significantly influences the decisions of venture capitalists (Brush, Carter, Greene, Hart \& Gatewood 2002). In support of the above notion, from a sample of 235 female-owned firms in the USA, 40 firms (representing 17\%) were able to secure funding from formal finance houses (Carter, Brush, Greene, Gatewood \& Hart 2003). According to Industry Canada (2005), consistent findings with regard to poor venture capital investments in female-led businesses compared to male-led firms have been reported in several countries across the globe.

The study by Orser, Riding and Manley (2006) advanced a different perspective with regard to fund seeking by gender. 
Orser et al. concluded that male business owners were actively involved in fund seeking compared to female business owners. According to Correia et al. (2011), venture capital markets are characterised by high transaction costs, and the number of buyers and sellers is very small. Therefore, venture capital markets are less efficient than public markets. When the observations by Correia et al. and those of Orser et al. are critically examined, they somehow suggest that a gender gap could exist in the access of venture capital. In their study, Changanti, DeCarolis and Deeds (1995), however, argued that gender plays an insignificant role in estimating small firms' capital structure owing to female entrepreneurs' preference for utilising internal as opposed to external equity. Research by Bennet and Dann (2000), as well as Haynes and Haynes (1999) further confirmed female entrepreneurs' preference for internal sources of finance compared to male entrepreneurs.

Orser et al. (2006) commented that although the findings of the above-mentioned studies lack in providing clear statistics on the application rates for different equity sources between male and female entrepreneurs (for comparative purposes), they do suggest that women may be less likely to obtain, let alone seek, external equity from a venture capital firm. Orser et al. noted that empirical studies further prove that an insignificant number of female-owned enterprises have received equity funding in the form of venture capital compared to their male counterparts. They concluded by proposing that further research is needed to establish possible causes of this discrepancy.

Richardson et al. (2004) established that in sub-Saharan Africa, female entrepreneurs are more likely to rely on internal and informal financing than are male entrepreneurs. The study by $\mathrm{Fu}, \mathrm{Ke}$ and Huang (2002) reported the existence of a positive relationship with venture profitability when equity finance is used. In Smolarski and Kut (2011), indications were made to suggest the existence of a significant relationship between financing and environmental instabilities. Smolarski and Kut focused on entities that pursued growth in local and international markets. For venture capitalists to invest in any given firm, large or small, risk of that firm plays a significant role. The concept of asymmetric information plays a pivotal role in explaining the risks emanating from funding entrepreneurial ventures regardless of the owner's or manager's gender.

\section{Gender, business risk, and access to finance}

Research has pointed out that risk aversion is one of the major reasons leading to entities' poor access to finance (Carter \& Shaw 2006; Marlow \& Carter 2006). In that regard, studies by Manning and Swaffield (2008), as well as Cronson and Gneezy (2009), revealed evidence that female entrepreneurs noticeably display high risk aversion and low self-esteem, among other traits. Manning and Swaffield lamented that the above-mentioned traits, combined with other psychological factors, largely compromise female entrepreneurs' financial negotiation capabilities, evidenced by poor access to finance (venture capital included).

The consequences of risk aversion in women are manifest in various areas; for example, women tend to lose confidence in their abilities, compromising the growth and success rate of their business entities. Resultantly, female entrepreneurs turn out to be reluctant in pursuing risky activities such as firm expansion and fund seeking, which are practices mainly carried out by profitable firms dominated by male entrepreneurs (Kwong, Jones-Evans \& Thompson 2011). Furthermore, Cliff (1998) found female entrepreneurs to be more anxious about the risks linked to speedy growth compared to their male counterparts. Consequently, female entrepreneurs deliberately adopt a slow and steady firm expansion rate. In addition, Cliff reported that for female entrepreneurs, personal considerations appeared to override economic considerations in relation to growing a business. Venture capitalists are investors whose primary concern is to grow businesses in order to buy them out within 5 years. The comments by Cliff emphasised that smaller firms, characterised by slower growth rate, appear to be women entrepreneurs' deliberate choices, and that venture capitalists may shy away from investing in female-owned business ventures, thereby creating a gender gap in access to venture capital.

Empirical evidence comparing female- and male-owned firms' access to formal and informal credit by country is limited. Available empirical evidence in this regard is readily available for developed countries such as the UK, USA, Canada, and New Zealand (Bruhn 2009; Demirgüç-Kunt, Klapper \& Singer 2013), whereas evidence from emerging countries is limited. In an attempt to compare access to formal and informal credit by gender, the study relies on evidence provided by Demirgüç-Kunt and Klapper (2012); the comparison was made relying on regions.

The respondents surveyed revealed their 1-year borrowing history in relation to formal and informal credit. South Africa is economically classified as a developing country. Thus, from Table 3, around 7\% of South Africa's women are likely to receive formal credit compared to $9 \%$ of men. Also, $22 \%$ of women would have access to informal credit compared to $26 \%$ of men. From Table 3, women in developing countries (including South Africa) have better access to formal credit when compared to countries in sub-Saharan Africa, Middle East and North Africa respectively. However, access to formal credit is still a challenge for women in developing countries when compared to women in developed countries. The trend is however different in relation to access to informal credit. Although men still have better access when compared to women by region, developing countries outperform high-income countries in the use of informal credit.

The following hypothesis was formulated:

$\mathbf{H}_{0}$ : There is no significant difference in the access of venture capital between male- and female-owned SMEs. 
TABLE 3: Men and women's access to formal and informal credit by region.

\begin{tabular}{lll}
\hline Variable & Women (\%) & Men (\%) \\
\hline Access to formal credit by region & & \\
Sub-Saharan Africa & $\leq 6$ & $>6$ \\
South Asia & $\leq 8$ & \pm 10 \\
Middle East and North Africa & $\leq 6$ & \pm 8 \\
Latin America & \pm 8 & \pm 9 \\
Europe and Central Asia & \pm 8 & \pm 9 \\
East Asia and Pacific & \pm 9 & \pm 9.5 \\
Developing economies & \pm 7 & \pm 9 \\
High-income economies & \pm 12 & \pm 17 \\
Access to formal credit by region & & \\
Sub-Saharan Africa & $\leq 39$ & $>40$ \\
South Asia & $\leq 29$ & \pm 32 \\
Middle East and North Africa & $\leq 32$ & \pm 35 \\
Latin America & \pm 15 & \pm 17 \\
Europe and Central Asia & \pm 25 & \pm 26 \\
East Asia and Pacific & \pm 22 & \pm 26 \\
Developing economies & \pm 22 & \pm 26 \\
High income economies & \pm 11 & \pm 12 \\
\hline Source: Demirgüç-Kunt, A. \& Klapper, L.F., 2012, Measuring financial inclusion: The global &
\end{tabular}

findex database, Policy Research Working Paper no. 6025, World Bank, Washington, DC

\section{Methodology}

The study was undertaken within a positivist paradigm where the focus is on facts and phenomena are reduced to their simplest elements. Positivism is a paradigm outlining that we can only see and observe things. Also, positivism emphasises that there is objective truth out there that waits to be discovered (Okeke 2015). In addition, it includes the formulation and testing of a hypothesis (O'Gorman \& MacIntosh 2015). The study relied on quantitative data and it is descriptive by design. Data collection was carried out by means of a survey. To gather data relevant to this empirical study, the researchers concentrated on single-owned SMEs and quota sampling was used. This is a sampling method in which the researcher selects units on the basis of pre-specified characteristics. In South Africa, the rates at which male and female individuals participate in self-employment stand at $51.5 \%$ and $48.5 \%$ respectively (GEM \& IFC 2005). A total of 109 questionnaires completed by 53 female and 56 male SME owners were returned with sufficient data to answer the research problem at hand. Respondents were initially drawn from the Eastern Cape province. However, the respondents were later drawn from all nine of South Africa's provinces as a measure to overcome the poor response rate. Small and medium-sized entities (SMEs) that participated in this study were identified through a random search on the Internet. Contact addresses were recorded and phone calls were placed to invite the entrepreneurs to participate in the study. Upon consent, each SME owner was asked to provide a valid email address to which the researcher then emailed the survey instrument.

\section{Reliability and validity of measurements}

The questionnaire consisted of items dealing with access to money and funds from venture capitalists, access to managerial expertise or training from venture capitalists, and access to technical expertise from venture capitalists as measures of access to venture capital. Respondents were questioned about accessibility of any of the above-mentioned indicators on a five-point Likert scale. The Cronbach's alpha coefficient was calculated to assess the internal reliability of items in the questionnaire and a coefficient value of 0.73 was obtained. To ensure that the study was valid, logical validity, which is a form of content validity, was applied. According to Phelan and Wren (2005), validity is a measure of quality in research. Thus validity is concerned with whether or not the study has successfully measured what it intended to measure. To ensure that the study took into account the required ranges as manifested by the variables under study (content validity), a thorough literature review was undertaken on the research problem. In addition, three experienced researchers in the field of entrepreneurship and finance were consulted (expert review) and their feedback was taken on board in designing the final research instrument (Mukwambo, Ngcoza \& Chikunda 2015).

\section{Data analysis}

Data analysis was carried out through the use of the Social Science Statistical Package (SPSS). The distribution scores of the study were reasonably normal and hence the parametric $t$-test and descriptive statistics were the statistical tools applied in the analysis and summarisation of data collected. The independent samples $t$-test was used to statistically analyse whether or not a significant difference existed between access to venture capital by gender. 'The independent samples $t$-test is used to find a difference between means of two independent samples for example, separate groups of subjects', (Nunez 2013:149). In this study the two groups are male and females SME owners. Thus, making use of the $t$-test, the researcher sought to establish whether the means of male and female SME owners were sufficiently different to conclude that they in fact are drawn from two distinct populations, namely the population with better access to venture capital and the population with poor access to venture capital, or whether the scores predicted that both samples were drawn from a single population (Nunez 2013:142). In addition, the effect size was also calculated to examine the effect of gender on access to venture capital indicator. According to Pallant (2010), to calculate the effect size for an independent sample test, two main methods are normally used, namely the eta squared and Cohen's d. In this article, the eta squared method was used because it has the smallest sampling variability, that is to say, it has the greatest precision (Keselman 1975; Skidmore \& Thompson 2013).

\section{Results}

This section outlines the results of the study. Descriptive results are presented and interpreted first. Thereafter, inferential results are presented.

\section{Descriptive statistics}

An independent samples $t$-test was conducted to compare access to venture capital indicator scores for men and women. 
Regarding access to money and funds from venture capitalists, results reveal that there is a statistically significant difference in the access to money from venture capitalists evidenced by a mean score for men $(M=3.79$, standard deviation $[\mathrm{SD}]=1.25)$ and women $(M=2.78, \mathrm{SD}=1.5$; $t(66.831)=3.07, p=0.003$, two-tailed). The magnitude of the difference in the means is above moderate to large (eta squared $=0.12$ ). Results also reveal that there is a statistically significant difference in the access to managerial expertise from venture capitalists as shown by mean scores for men $(M=3.88, \mathrm{SD}=1.25)$ and women $(M=2.8, \mathrm{SD}=1.5$; $t(66.953)=3.18, p=0.002$, two-tailed). Similarly, the magnitude of the difference in the means is above moderate to large (eta squared $=0.13$ ). In addition, results reveal that there is a statistically significant difference in accessing technical expertise from venture capitalists, supported by mean scores for men $(M=3.88, \mathrm{SD}=1.32)$ and women $(M=2.97$, $\mathrm{SD}=1.59 ; t(66.882)=2.607, p=0.011$, two-tailed). Furthermore, the magnitude of the difference in the means is above moderate to large (eta squared $=0.09$ ).

\section{Inferential statistics}

The study's hypothesis, stating that there is no significant difference in the access of venture capital between male and female SME owners, was tested. Results from the independent samples $t$-test conducted to compare access to venture capital mean scores for men and women reveal that there is a statistically significant difference in mean scores for men $(M=3.85, \mathrm{SD}=1.25)$ and women $(M=2.86, \mathrm{SD}=1.51$; $t(66.802)=3.005, p=0.004$, two-tailed). The magnitude of the differences in the means was above moderate to large (eta squared $=0.12$ ).

\section{Discussion}

The descriptive statistics suggest that gender has an influence on SMEs' access to venture capital. Thus, male entrepreneurs have better access to venture capital when all indicators (access to funding, access to managerial expertise, and access to technical expertise) are compared between genders. In addition, these results add evidence to literature that argues that a gender gap exists in accessing of venture capital by SMEs. The findings from inferential statistics confirm the suggestion made from an analysis of descriptive statistics. The results reveal that gender has a significant influence on the access of venture capital by SMEs, thus leading to this study rejecting the null hypothesis. These results are consistent with findings by Klapper and Parker (2011) who revealed that female-led SMEs are less likely to access finance from formal venture capital providers. Brush et al. (2004) also concluded that female-owned SMEs generally raise less formal and informal venture capital than male-owned SMEs. However, Watson, Newby and Mahuka (2009) pointed out that the finance gap from the demand side could be a result of many factors that women entrepreneurs consider crucial when they are making decisions related to the capital structure of the firm. These issues include risk-taking propensity and the desire to retain full ownership of the entity. Women entrepreneurs' approach to business differs significantly from that of men, including the amount of risk they wish to take. Female entrepreneurs generally prefer less risk as is evidenced by their dominance in the retail sector characterised by low growth as opposed to the service sector characterised by high growth and high risk. The risk-averse nature of female entrepreneurs and the desire to retain full entity ownership discourage female entrepreneurs from seeking external equity, leading to a gender gap in access to venture capital. The study's findings also point to the reluctance of female entrepreneurs to seek external equity in the form of venture capital compared to male entrepreneurs, as is evident in the large differences between male and female access to venture capital mean scores (access to funds $=1.01$, access to managerial expertise $=1.08$, access to technical expertise $=0.97$ )

\section{Recommendations}

Although there is no evidence to suggest that South African female entrepreneurs' business concepts or ideas are evaluated differently from those of male entrepreneurs by venture capital fund managers, for the purposes of funding, in many instances, societies benefit overall from venture capital firms with women partners (Brush, Carter, Gatewood, Greene \& Hart 2006). In a global community with at least half of the working population being self-employed, there is a high probability that venture capital firms with women partners are more likely to fund women-founded SMEs (Brush et al. 2006; Cho, Robalino \& Watson 2016). This is likely to be the case given that in different societies women are among the vulnerable (Cho et al. 2016; Vidovic, Peric \& Jozanc 2015).

In an attempt to empower female entrepreneurs, it is logical for female venture capitalists to play a leading role. Therefore, it is crucial for the established South African female business community to support budding female entrepreneurial activities through committing various resources in the venture capital sector. In addition, it might further help women business owners to enhance strategic connections through business networks essential for business success, such as consistent access to accountants, lawyers, and investment bankers. The concerned stakeholders, such as the South African government, private players within the business community, and non-governmental organisations, can increase female-owned SMEs' access to venture capital by educating venture capitalists on issues affecting the capital structure decisions of female-owned SMEs. Venture capitalists, to a certain degree, have little experience in concluding business transactions with women business owners because their focus is mainly on entities with the capacity of listing on the public stock exchange. The aforementioned stakeholders should design and implement programmes that create an environment where a business owner's risk-taking propensity level is easily learned and assessed. According to Vidovic et al. (2015), evidence exists suggesting that women entrepreneurs generate viable business ideas and exploit entrepreneurial opportunities at 
the same rate as men. When evaluating business concepts for eligibility of funding, it is important for venture capitalists to take into consideration women entrepreneurs' business goals, approach to business, and risk-taking propensity as these significantly differ when compared to their male counterparts (Watson et al. 2009). This will in turn promote venture capital lending to women, as perceptions about women's abilities are proved to be incorrect. There is a need for non-financial support to women entrepreneurs to enhance their managerial and technical competencies. Female business owners should also form networks that will assist them to link with other successful female entrepreneurs as a way of boosting their confidence. In addition, there is a need to have support programmes that provide women entrepreneurs with proper information with regard to the advantages of utilising venture capital as a source of finance.

\section{Limitations of the study}

This study focused on access to venture capital from the demand side and ignored the supply side. Further studies can be carried out to assess the influence of gender on access to venture capital focusing on both the demand side and the supply side.

\section{Conclusion}

This article has highlighted that dissimilar access to venture capital between genders can be found in South Africa. The article concludes that a gender gap in access to venture capital exists owing to differences in business approach between female entrepreneurs and their male counterparts. Female entrepreneurs are cautious about the level of risk they are willing to take and the amount of control they wish to exercise in firm ownership.

\section{Acknowledgements Competing interests}

The author declares that he has no financial or personal relationships that may have inappropriately influenced him in writing this article.

\section{References}

Bennet, R. \& Dann, S., 2000, 'The changing experience of Australian female entrepreneurs', Journal of Gender, Worker and Organisation 7(2), 75-83. https:// doi.org/10.1111/1468-0432.00095

Bruhn, M., 2009, Female-owned firms in Latin America: Characteristics, performance, and obstacles to growth, World Bank Policy Research Paper 5122, World Bank, Washington, DC.

Brush, C., Carter, N., Greene, P.G., Hart, M. \& Gatewood, E., 2002, 'The role of social capital and gender in linking financial suppliers and entrepreneurial firms: A framework for future research', Journal of Venture Capital 4(4), 305-323. https://doi.org/10.1080/1369106022000024897

Brush, C.G., Carter, N.M., Gatewood, E.J., Greene, P.G. \& Hart, M.M., 2004, Clearing the hurdles: Women building high growth businesses, FT/Prentice Hall, Upper Saddle River, NJ.

Brush, C.G., Carter, N.M., Gatewood, E.J., Greene, P.G. \& Hart, M.M., 2006, Growthoriented women entrepreneurs and their businesses: A global research perspective, Edward Elgar, Cheltenham, UK.

Cant, M. \& Wiid, J., 2013, 'Establishing the challenges affecting South African SMEs', International Business and Economics Research Journal 12(6), 707-715. https:// doi.org/10.19030/iber.v12i6.7869

Carter, N., Brush, C.G., Greene, P.G., Gatewood, E. \& Hart, M.M., 2003, 'Women entrepreneurs who break through to equity financing: The influence of human capital', Journal of Venture Capital 5(1), 1-28. https://doi.org/10.1080/1369 106032000082586

Carter, S. \& Shaw, E., 2006, Women's business ownership: Recent research and policy development, Small Business Service Research, London.

Carter, S., Shaw, E., Wilson, F. \& Lam, W., 2006, Gender, entrepreneurship and business finance: Investigating the relationship between banks and entrepreneurs in the UK, in growth-oriented woman entrepreneurs and their businesses: A global research perspective, New Horizons in Entrepreneurship, Edward Elgar Publishing, Cheltenham, UK.

Changanti, R., DeCarolis, D. \& Deeds, D., 1995, 'Predictors of capital structure in small ventures', Journal of Entrepreneurship Theory and Practice 20(2), 7-18.

Cho, Y., Robalino, D. \& Watson, S., 2016, 'Supporting self-employment and small-scale entrepreneurship: Potential programs to improve livelihoods for vulnerable workers', IZA Journal of Labour Policy 5(1), 1. https://doi.org/10.1186/s40173016-0060-2

Cliff, J.E., 1998, 'Does one size fit all? Exploring the relationship between attitudes to growth, gender and business size', Journal of Business Venturing 13, 523-542. https://doi.org/10.1016/S0883-9026(97)00071-2

Correia, C., Flynn, D., Uliana, E. \& Wormald, M., 2011, Financial management, 7th edn., Juta, Cape Town.

Cronson, R. \& Gneezy, U., 2009, 'Gender differences in preferences', Journal of Economic Literature 47(2), 448-474. https://doi.org/10.1257/jel.47.2.448

Cumming, D.J. \& Johan, S.A., 2013, Venture capital and private equity contracting: An international perspective, 2nd edn., Elsevier, London.

Demirgüç-Kunt, A. \& Klapper, L.F., 2012, Measuring financial inclusion: The global findex database, Policy Research Working Paper no. 6025, World Bank, Washington, DC

Demirgüç-Kunt, A., Klapper, L.F. \& Singer, D., 2013, Financial inclusion and lega discrimination against women: Evidence from developing countries, Policy Research Working Paper no. 6416, World Bank, Washington, DC.

Derera, E., Chitakunye, P. \& O'Neill, C., 2014, 'The impact of gender on start-up capital: A case of women entrepreneurs in South Africa', Journal of Entrepreneurship 23(1), 95-114. https://doi.org/10.1177/0971355713513355

Dorsey, T., 1979, Operating guidelines for effective venture capital funds management, \#3 in a Technical Series, University of Texas, Austin, TX.

Ellis, A., Cutura, J., Dione, N., Gillison, I., Manuel, C. \& Thongori, J., 2007, Gender and economic growth in Kenya: Unleashing the power of women, World Bank, Washington, DC.

Faisel, A., 2004, 'Impact assessment of Kashf's Microfinance and Karvaan Enterprise Development Program', report prepared for DIFD Pakistan, Arjum and Associates, Islamabad.

Fatoki, O., 2012, 'The influence of entrepreneurial orientation on access to debt finance and firm performance of small and medium enterprises in South Africa', Journal of Social Sciences 32(2), 121-131. https://doi.org/10.1080/09718923.201 2.11893058

Fatoki, O. \& Smit, V.A., 2011, 'Constraints to credit access by new SMEs in South Africa: A supply-side analysis', African Journal of Business Management 5(4), 1413-1425.

Flowers, D., Parker, H., Arenz, J., Gaffley, J., Greighton, L., Fredricks, L. et al., 2013, 'An exploratory study on corporate governance practices in small and micro fast moving consumer goods enterprises in the Cape Metropole, Western Cape, South moving consumer goods enterprises in the Cape Metropole, Western
Africa', African Journal of Business Management 7(22), 2119-2125.

$\mathrm{Fu}, \mathrm{T} ., \mathrm{Ke}, \mathrm{W}$. \& Huang, Y., 2002, 'Capital growth, financing source and profitability of small business: Evidence from Taiwan small enterprises', Small Business Economics 18, 257-267. https://doi.org/10.1023/A:1015291605542

Gitman, L.J., Smith, M.B., Hall, J., Lowies, B., Marx, B., Strydom, B. et al., 2010, Principles of managerial finance: Global and Southern African perspectives, Pearson Education South Africa (Pty) Ltd., Cape Town

Global Entrepreneurship Monitor (GEM) \& International Finance Corporation (IFC), 2005, Gender and growth assessment for Uganda: Gender perspective on legal and administrative barriers to investment, World Bank, Washington, DC.

Gompers, P. \& Lerner, J., 2001, 'The venture capital revolution', Journal of Economic Perspectives 15, 145-168. https://doi.org/10.1257/jep.15.2.145

Greene, P.G., Brush, C.G., Hart, M.M. \& Saparito, P., 2001, 'Patterns of venture capital funding: Is gender a factor?', Venture Capital: An International Journal of Entrepreneurial Finance 3(1), 63-83. https://doi.org/10.1080/1369106
0118175

Haynes, G.W. \& Haynes, D.C., 1999, 'The debt structure of small business owned by women in 1987 and 1993', Journal of Small Business Management 37(2), 1-19.

Industry Canada, 2005, Summary report from sustaining the momentum. An economic forum on women entrepreneurs, Sprott School of Business and Industry Canada, Ottawa, Canada.

Jeng, L.A. \& Wells, P.W., 2000, 'The determinants of venture capital funding: Evidence across countries', Journal of Corporate Finance 6, 241-289. https://doi.org/ 10.1016/S0929-1199(00)00003-1

Keselman, H.J., 1975, 'A Monte Carlo investigation of three estimates of treatment magnitude: Epsilon squared, eta squared, and omega squared', Canadian Psychological Review 16, 44-48. https://doi.org/10.1037/h0081789

Klapper, L.F. \& Parker, S.C., 2011, 'Gender and the business environment for new firm creation', The World Bank Research Observer 26, 237-257. https://doi.org/ 10.1093/wbro/lkp032

Korteweg, A. \& Nagel, S., 2016, 'Risk-adjusting the returns to venture capital', The Journal of Finance 71(3), 1437-1470. https://doi.org/10.1111/jofi.12390 
Kortum, S. \& Lerner, J., 2000, 'Assessing the contribution of venture capital to innovation', The Rand Journal of Economics 31(4), 674-692. https://doi.org/10. innovation, The

Kumar, D., Hossain, A. \& Gope, M.C., 2015, 'Role of micro credit program in empowering rural women in Bangladesh: A study on Grameen Bank Bangladesh Limited', Asian Business Review 3(4), 114-120. https://doi.org/10.18034/abr. v3i4.287

Kwong, C., Jones-Evans, D. \& Thompson, P., 2011, 'Differences in perceptions of access to finance between potential male and female entrepreneurs', Internationa Journal of Entrepreneurial Behaviour and Research 18(1), 75-97. https://doi. org/10.1108/13552551211201385

Lucey, B.M., 2010, 'Determinants of capital structure of Irish SMEs', Journal of Small Business Economics 35(3), 1-25.

Manning, A. \& Swaffield, J., 2008, 'The gender pay gap in early-career wage growth', Economic Journal 113(530), 983-1024. https://doi.org/10.1111/j.1468-0297. 2008.02158.x

Marlow, S. \& Carter, S., 2006, 'If you don't ask you don't get! Women, self-employmen and finance', paper presented at the Warwick Business School Small Form Finance Conference, Warwick University, Coventry, 4-5 April.

Memba, S.F., Gakurwe, W.R. \& Karanga, K., 2012, 'Venture Capital (VC): Its impact on growth of small and medium enterprises in Kenya', International Journal of Business and Social Science 3(6), 32-38.

Mukwambo, M., Ngcoza, K. \& Chikunda, C., 2015, 'How researchers define and measure variables', in C. Okeke \& M. van Wyk (eds.), Educational research: An African approach, pp. 186-206, Oxford University Press, Southern Africa, Cape Town.

Muravyev, A., Schafer, D. \& Talavera, O., 2009, 'Entrepreneurs' gender and financial constraints: Evidence from international data', Journal of Comparative Economics 37, 270-286. https://doi.org/10.1016/j.jce.2008.12.001

Naidoo, S., Hilton, A. \& Natalie, G., 2006, Access to finance for women entrepreneurs in South Africa: Challenges and opportunities, IFC/DTI/Finmark Trust, Pretoria.

Noguera, M., Alvarez, C., Merigó, J.M. \& Urbano, D., 2015, 'Determinants of female entrepreneurship in Spain: An institutional approach', Computational and Mathematical Organization Theory 21(4), 341-355. https://doi.org/10.1007/ Mathematical Organiz

Nunez, D., 2013, 't-tests', in C. Tredoux \& K. Durrheim (eds.), Number, hypotheses and conclusions: A course in statistics for the social sciences, 2 nd edn., pp. 142-159, Juta, Cape Town.

O'Gorman, K. \& Macintosh, R., 2015, Research methods for business and management, 2nd edn., Good Fellow Publishers, Oxford, UK.
Okeke, C., 2015, 'Achieving qualitative validity, reliability and generalisability', in C. Okeke \& M. van Wyk (eds.), Educational research: An African approach, pp. 207-223, Oxford University Press, Southern Africa, Cape Town.

Orser, B.J., Riding, A.L. \& Manley, K., 2006, 'Women entrepreneurs and financial capital', Entrepreneurship Theory and Practice 30(5), 643-665. https://doi.org/ 10.1111/j.1540-6520.2006.00140.x

Osnabrugge, M., 2000, 'A comparison of business angel and venture capitalists investment procedures: An agency theory-based analysis', Venture Capital 2(2), 91-109. https://doi.org/10.1080/136910600295729

Pallant, J., 2010, SPSS survival manual, 4th edn., McGraw-Hill, London.

Phelan, C. \& Wren, J., 2005, 'Exploring reliability in academic assessment', viewed 17 April 2017, from https://www.uni.edu/chfasao/reliabilityandvalidity.htm

Richardson, P., Howarth, R. \& Finnegan, G., 2004, The challenges of growing small business: Insights from women entrepreneurs in Africa, SEED Working Paper 47 ILO, Geneva.

Skidmore, T.S. \& Thompson, B., 2013, 'Bias and precision of some classical ANOVA effect sizes when assumptions are violated', Behavioural Research Methods 45(2), 536-546. https://doi.org/10.3758/s13428-012-0257-2

Small Enterprise Development Agency (SEDA), 2016, Sources of finance: Private equity, viewed 15 November 2016, from http://www.seda.org.za/MyBusiness/ Factsheets/Pages/PrivateEquity.aspx

Smolarski, J. \& Kut, C., 2011, 'The impact of venture capital financing method on SME performance and internationalization', International Entrepreneurship Management Journal 7, 39-55. https://doi.org/10.1007/s11365-009-0128-1

South African Venture Capital Association (SAVCA), 2013, 'Private equity growth in 2012 surpasses the previous four years combined', viewed 05 April 2016, from http://www.savca.co.za/news/item.aspx?id=222

South African Venture Capital Association (SAVCA), 2015, Venture capital and private equity industry performance survey performance of Southern Africa covering the 2015 calendar year, SAVCA, Johannesburg, South Africa.

South African Venture Capital Association (SAVCA), 2016, Private equity fundraising for Southern Africa reaches record high, viewed 20 November 2016, from http:// www.africa-assets.com/news/savca-private-equity-fundraising-southern-africareaches-record-high

Vidovic, D., Peric, J. \& Jozanc, N., 2015, 'The role of social entrepreneurship in empowerment of women in rural areas of Croatia', Economy of Eastern Croatia Yesterday, Today, Tomorrow 4, 713-726.

Watson, J., Newby, R. \& Mahuka, A., 2009, 'Gender and the SME "finance gap", International Journal of Gender and Entrepreneurship 1(1), 42-56. https://doi. org/10.1108/17566260910942336 